UNDERGRADUATE RESEARCH IN NATURAL AND CLINICAL SCIENCE AND TECHNOLOGY (URNCST) JOURNAL Read more URNCST Journal articles and submit your own today at: https://www.urncst.com

\title{
Is Hinokitiol Efficacious Against an Antimicrobial- Resistant Strain of Streptococcus pyogenes? A Research Protocol
}

Amir-Ali Golrokhian-Sani, BHSc Student [1]*, Yunbo Jiang, BHSc Student [1], Sinan Kaka, BHSc Student [1], Olamide Olanrewaju, BHSc Student [1]

[1] Faculty of Health Sciences, Queen's University, Kingston, Ontario, Canada K7L 3N6

*Corresponding Author: 19aags@queensu.ca

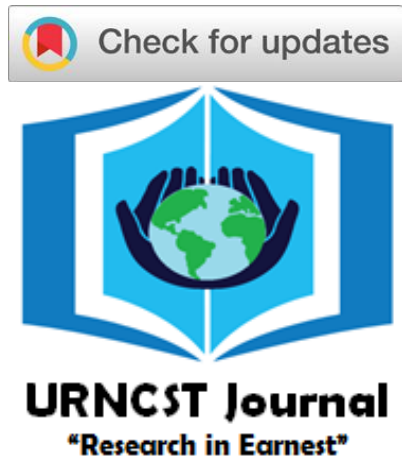

\begin{abstract}
Introduction: Streptococcus pyogenes, a highly infectious and deadly gram-positive bacterium in the Group A Streptococcus family, that causes respiratory and skin infections. Treatments include oral penicillin and macrolides; however, penicillin and macrolide-resistant Streptococcus pyogenes (e.g., A458) are emerging. Hinokitiol, beta-thujaplicin, has been thought to be an alternative solution to help fight against antimicrobial resistant strains of $S$. pyogenes as several studies have highlighted its bactericidal effects. These effects in turn, inhibit the production of bacterial adenosine triphosphate and bacteriostatic effects (growth inhibition) of hinokitiol on a related bacterium, Streptococcus pneumoniae and a variant of Streptococcus pyogenes, SSI-9. Furthermore, hinokitiol was found to be very efficacious against a penicillin and macrolide resistant gram-positive bacterium, indicating that penicillin and macrolides likely have a different mechanism of action from hinokitiol. This suggests that microbes are likely not resistant to hinokitiol. Therefore, by extrapolating this data, it is thought that hinokitiol may be efficacious in combatting A458, a concerning antimicrobial resistant strain of Streptococcus pyogenes.

Methods: Every step would be performed under triple-blind conditions. Using a solvent control, penicillin G, streptomycin, and hinokitiol, an efficacy trial would be undertaken to evaluate the bactericidal/inhibitory effects of each drug and determine whether hinokitiol is superior to the current gold-standards. A two-way analysis of variance and multiple repeated-measures analysis of variance will be used to evaluate efficacy.

Results: It is expected that hinokitiol is efficacious against the resistant strain of Streptococcus pyogenes, A458 unlike streptomycin.

Discussion: The strengths of this study are that a novel treatment was used and the experiment was conducted as a tripleblinded experiment. The limitations include its efficiency and the lack of knowledge of the treatment. The statistical test conducted for this study would evaluate whether hinokitiol has a statistically significant effect on a resistant strain of Streptococcus pyogenes.

Conclusion: It is likely that hinokitiol will show a resistance-free effect on the two strains of Streptococcus pyogenes. This is a significant undertaking due to the dangers of antimicrobial-resistant Streptococcus pyogenes. However, further experiments need to be conducted to support this hypothesis.
\end{abstract}

Keywords: Streptococcus pyogenes; gram-positive bacteria; Streptococcus pneumoniae; antimicrobial resistance; antibiotics; hinokitiol (beta-thujaplicin); Hiba arborvitae; bactericidal

\section{Introduction}

Streptococcus pyogenes ( $S$. pyogenes) is a grampositive, group A, catalase-negative, streptococcus bacterium with a chain-like structure [1]. It is a highly infectious bacterium, most prevalent in developing countries, where there is limited or no access to medical treatment. S. pyogenes can be transmitted via air droplets, body contact, open wounds, and contaminated surfaces, thus an area with high population density would also be at risk [1]. Its symptoms are pharyngitis, sore throat caused by an $S$. pyogenes infection, soft-tissue infections and respiratory infections [1]. According to the World Health Organization
(WHO), it is the $9^{\text {th }}$ deadliest infectious microbe with yearly totals of 400,000 deaths worldwide and just under 2 million reported cases [1]. Those with weak immune systems, namely young children and immunocompromised individuals, are the most at risk of severe illness from $S$. pyogenes [1]. Treatments for infections of $S$. pyogenes include oral penicillin and macrolides as a second option for people allergic to penicillin [1]. Penicillin remains the goldstandard treatment for $S$. pyogenes due to its cost, safety, and specificity. Although within the past 20 years there has been concern of reduced efficacy against the bacterium as the rate of penicillin failure has increased by almost $40 \%$ in some 
UNDERGRADUATE RESEARCH IN NATURAL AND CLINICAL SCIENCE AND TECHNOLOGY (URNCST) JOURNAL Read more URNCST Journal articles and submit your own today at: https://www.urncst.com

regions [2].This can potentially be explained by factors such as the relative inability of penicillin to go into tonsil tissue, bacterial combination of $S$. pyogenes with $M$. catarrhalis increasing its rate of colonization, protection by the surrounding $\beta$-lactamase producing bacteria of the mouth and editing of commensal bacteria causing competition for nutrition [2]. Macrolide-resistant $S$. pyogenes have also started to emerge [1]. Reasons for this include an increased antibiotic consumption over time and genetic changes in the bacterium [2]. This is troubling as antimicrobial resistance (AMR) is a continuously growing problem, with the WHO predicting that it could cause 10 million deaths annually by 2050 [3].

Hinokitiol, beta-thujaplicin, is a tropolone-based compound extracted from the roots of Hiba arborvitae, a species of pine originating from Japan [4]. It exhibits antiinflammatory, antioxidant, and antibacterial activities and has been thought to be an alternative solution to help fight against antimicrobial resistant strains of S.pyogenes as microbes have not yet had a chance to develop resistance to hinokitiol [4].

A previous study, conducted by Domon and his team, tested the inhibitory and bactericidal effects of hinokitiol on a few gram-positive and negative bacteria [4]. One of the gram-positive bacteria was S. pyogenes (SSI-9), a subtype of the emm1 group [4-5]. The inhibitory and bactericidal activity of hinokitiol on S. pyogenes (SSI-9) was found by adding hinokitiol to the bacterial suspension under appropriate conditions [4]. Domon and his team discovered that the bacteria was inhibited and killed after one hour at around the same hinokitiol concentration of 0.3 micrograms/mL or $1.8 \mu \mathrm{M}$ [4]. Domon and his team discovered that treatment at roughly $0.3 \mu \mathrm{g} / \mathrm{mL}$ decreased the strains viability by more than $99 \%$ [4]. The bactericidal activity was checked by determining the amount of bacterial ATP production [4]. The researchers found that hinokitiol inhibited bacterial ATP production in S. pyogenes SSI-9 [4].

The mechanism of action of hinokitiol is not fully understood and should be further investigated [4]. Researchers like Trust et al. have hypothesized that hinokitiol may be more efficacious against gram-positive bacteria due to the structural differences between the two types of bacteria [4]. Gram-negative bacteria possess an outer membrane that acts like a permeability barrier to hinokitiol, a hydrophobic agent [4]. This explains why hinokitiol was more efficacious against gram-positive bacteria in the research conducted by Domon and his team [4]. However, further research is required as the exact mechanism remains unknown [4]. Since resistance is developing in S. pyogenes (A458) towards its treatments, one of which being macrolides and hinokitiol was hypothesized to be more efficacious against gram-positive bacterium, we hypothesize that hinokitiol may act as an alternative treatment against the antibiotic resistant strain, S. pyogenes (A458). Although the exact mechanism of action of hinokitiol is unknown, we believe that hinokitiol has a different mechanism of action from penicillin and macrolides as Domon and his team found that hinokitiol was very efficacious against other gram-positive bacterium like S. pneumoniae (KM256), which has antibiotic resistance to penicillin and macrolides [4].

Another study conducted by Isono and his team further tested the efficacy of hinokitiol in treating mice infected with an antibiotic resistant strain of $S$. pneumoniae [5]. The mice were infected with an antimicrobial-susceptible strain $(S$. pneumoniae D39) and a macrolide-resistant strain (S. pneumoniae NU4471). One hour after tracheal administration, it was seen that hinokitiol significantly decreased the amount of both strains of Streptococcus pneumoniae in the bronchoalveolar lavage fluid and the concentration of pneumococcal DNA in the serum [5]. Those results further indicate that macrolides likely have a different mechanism of action compared to hinokitiol, increasing the likelihood that $S$. pyogenes (A458) is not resistant to hinokitiol.

Upon reviewing previous literature, hinokitiol has been found to be efficacious against gram-positive bacteria and likely has a different mechanism of action compared to macrolides and penicillin. This makes it a possible alternative and novel treatment in combating a concerning AMR, gram-positive strain of $S$. pyogenes (A458) with a dwindling number of efficacious treatments [4, 6-7].

\section{Methods}

All testing shall be triple-blinded, with the researchers and statisticians both being kept unaware of any of the variables in question. All labels will be removed and replaced with computer-assigned, randomly generated tags.

As $S$. pyogenes is a highly contagious airborne microbe, standard contamination prevention protocols will be employed, such as the frequent sterilization of equipment and the use of an isolation glove box to completely isolate the sample and prevent airborne infections while conducting research.

The emm1 strain is the most common and accessible strain of $S$. pyogenes, making it a good, non-resistant representation of the bacterium. Additionally, A458 is another, highly resistant strain of $S$. pyogenes, which makes it ideal for comparisons with emm1 when it comes to drug response $[2,8]$. These two strains will be cultured in Todd Hewitt Broth, an enrichment medium favouring the growth of hemolytic bacteria, such as $S$. pyogenes, within an Anaerobic Jar at $37^{\circ} \mathrm{C}$, as $S$. pyogenes is an anaerobic coccus and would fail to grow in the presence of oxygen, and $37^{\circ} \mathrm{C}$ is the most optimal temperature for microbial growth [6].

Each dish will have both substances added and be monitored over the next 24 hours for their spread and percent cell death through a MTT Assay. This is used to determine the quantity of cells that can still undergo metabolism using MTT, which will attach to aldehyde dehydrogenase, an enzyme in the electron transport chain of cellular metabolism and change colour from yellow MTT to dark blue Formazan, 
UNDERGRADUATE RESEARCH IN NATURAL AND CLINICAL SCIENCE AND TECHNOLOGY (URNCST) JOURNAL Read more URNCST Journal articles and submit your own today at: https://www.urncst.com

where the darker the blue expression, the more viable cells there are [9].

Next, the actual effect of hinokitiol will be analyzed. This will require a solvent control, penicillin $\mathrm{G}$ (the goldstandard medication that ignores resistance), Streptomycin (the gold-standard medication that A458 resists), and hinokitiol. All three (non-solvent control) substances would be at concentrations of $0.0003,0.003,0.03,0.3,3$, and 30 $\mu \mathrm{g} / \mathrm{mL}$, which will lead to a total of 24 test combinations (Table 1) [10]. This broad range of concentrations should allow for the calculation of EC50 for hinokitiol.

Table 1. Combinations for treatments and their concentrations.

\begin{tabular}{|l|}
\hline Solvent Control Combinations \\
\hline Solvent control $(0.0003 \mu \mathrm{g} / \mathrm{mL})$ \\
\hline Solvent control $(0.003 \mu \mathrm{g} / \mathrm{mL})$ \\
\hline Solvent control $(0.03 \mu \mathrm{g} / \mathrm{mL})$ \\
\hline Solvent control $(0.3 \mu \mathrm{g} / \mathrm{mL})$ \\
\hline Solvent control $(3 \mu \mathrm{g} / \mathrm{mL})$ \\
\hline Solvent control $(30 \mu \mathrm{g} / \mathrm{mL})$ \\
\hline Penicillin $\mathrm{G}(0.0003 \mu \mathrm{g} / \mathrm{mL})$ \\
\hline Penicillin $\mathrm{G}(0.003 \mu \mathrm{g} / \mathrm{mL})$ \\
\hline Penicillin $\mathrm{G}(0.03 \mu \mathrm{g} / \mathrm{mL})$ \\
\hline Penicillin $\mathrm{G}(0.3 \mu \mathrm{g} / \mathrm{mL})$ \\
\hline Penicillin $\mathrm{G}(3 \mu \mathrm{g} / \mathrm{mL})$ \\
\hline Penicillin $\mathrm{G}(30 \mu \mathrm{g} / \mathrm{mL})$ \\
\hline Streptomycin $(0.0003 \mu \mathrm{g} / \mathrm{mL})$ \\
\hline Streptomycin $(0.003 \mu \mathrm{g} / \mathrm{mL})$ \\
\hline Streptomycin $(0.03 \mu \mathrm{g} / \mathrm{mL})$ \\
\hline Streptomycin $(0.3 \mu \mathrm{g} / \mathrm{mL})$ \\
\hline Streptomycin $(3 \mu \mathrm{g} / \mathrm{mL})$ \\
\hline Streptomycin $(30 \mu \mathrm{g} / \mathrm{mL})$ \\
\hline Hinokitiol $(0.0003 \mu \mathrm{g} / \mathrm{mL})$ \\
\hline Hinokitiol $(0.003 \mu \mathrm{g} / \mathrm{mL})$ \\
\hline Hinokitiol $(0.03 \mu \mathrm{g} / \mathrm{mL})$ \\
\hline Hinokitiol $(0.3 \mu \mathrm{g} / \mathrm{mL})$ \\
\hline Hinokitiol $(3 \mu \mathrm{g} / \mathrm{mL})$ \\
\hline Hinokitiol $(30 \mu \mathrm{g} / \mathrm{mL})$ \\
\hline
\end{tabular}

The substances will all be injected into the agar using a micropipette. 50 Petri dishes shall be required at the minimum. Half of these dishes will have emm1, and half will have A458. Each dish will have $40-\mu \mathrm{L}$ in the Todd Hewitt broth [4]. The randomly selected respective treatments each get roughly $4-\mu \mathrm{L}$ worth of space where they will be added and left in anaerobic conditions. A sample will be taken out at 1, 2, and 24 hours. As hinokitiol is relatively fast-acting, the first two samples need to be close together to gather relevant data while the final measurement behaves as a follow-up, checking for any unpredicted behaviour in the long-term [4]. The Petri dishes shall be measured for the inhibition of bacterial viability, where an MTT assay will be done over a period of 24 hours at an interval [4], until there are no viable $S$. pyogenes were left in the sample to determine the efficacy of hinokitiol compared to the sample treated with penicillin $G$ and the sample treated with Streptomycin. The results of which can then be plotted on a line graph to determine the half-life of the $S$. pyogenes under the 3 treatments to determine which is more efficacious. The methodology will be repeated a total of 3 times to account for unforeseen errors that may affect 1 series of tests.

For the efficacy component, the primary statistical test between the treatment groups will be a two-way ANOVA that will account for both bacterial strains. To compare effects between 1, 2, and 24 hours, a RM ANOVA can be performed.

All analyses will be performed using IBM Statistical Package for the Social Sciences (SPSS) 27.0. The significance will be at $\alpha=.05$ so any calculated $p$-value less than the $\alpha$ will be considered statistically significant.

\section{Results}

Assuming a rejection of the null hypothesis, we anticipate that hinokitiol is efficacious against the resistant strain of $S$. pyogenes (A458) as hinokitiol was found to be efficacious against gram-positive bacteria like $S$. pyogenes (emm1). This is likely because gram-positive bacteria have no outer membrane to protect them against hydrophobic molecules like hinokitiol. Plus, hinokitiol likely has a novel mechanism of action compared to other treatments so bacteria have not had the time to develop resistance to it [4].

Once the bacterial cultures and machinery are acquired, and the experiment has started, we will observe the effects of the four treatment groups (hinokitiol, streptomycin, penicillin $G$ and the solvent control) at different points in time ( 24 hours and 48 hours) on the non-resistant strain (emm1) and the resistant strain (A458). Once the data is collected, it will be statistically analyzed.

\section{Discussion}

A major strength of the methodology is its triple-blinded construction. This can come at a slightly reduced efficiency, but that is more than worth the reduced bias. The sample size is also very respectable ( $\geq 50$ ), although taking samples at tighter intervals would be helpful for the RM ANOVAs. That would come with the drawback of either needing numerous Petri dishes or opening the anaerobic containers more frequently to take samples, which is why the methodology sticks to only 1,2 , and 24 hours later. 
UNDERGRADUATE RESEARCH IN NATURAL AND CLINICAL SCIENCE AND TECHNOLOGY (URNCST) JOURNAL Read more URNCST Journal articles and submit your own today at: https://www.urncst.com

An additional benefit of this study is that it plans on analyzing the efficacy of a relatively novel treatment in hinokitiol which may be able to add a new treatment in the fight against rapidly emerging AMR strains of $S$. pyogenes as the efficacy of current treatments like penicillin and macrolides is beginning to wane. We also made sure to use strains that have yet to be tested. However, the novelty of the treatment means that there is a lack of literature based on the mechanism of action of the treatment, its effective dosage, and its effects on other bacteria. These issues could be addressed in future studies.

The expected results of the two-way ANOVA would demonstrate penicillin $G$ to be effective in inhibiting bacterial viability on all strains and Streptomycin to be efficacious against emm1 strain but have no effect on the solvent control, as it is resistant to the drug. Based on past research, hinokitiol has demonstrated that it is effective in treating S. pyogenes, but its efficacy against common antibiotics, such as penicillin $\mathrm{G}$ has yet to be determined, which is the goal of this study. The RM ANOVAs for comparing 1, 2, and 24 hours will be analyzed to see how the trend shifts over time. This will demonstrate a decreased rate of action for hinokitiol as it is relatively fast-acting $(<<24$ hours) [4].

Our research study lacks variety in the number of strains and treatments unlike other similar studies (e.g. Domon et al). As we have, only two strains (A458 and SSI-9) and 4 treatments (penicillin, streptomycin, hinokitiol and a solvent control). This limits the generalizability of our research study as we are only able to standardize these results with the strains and treatments listed and not other ones. So, for this experiment the amount of treatments and strains could be expanded to increase generalizability.

\section{Conclusions}

This proposed project intends to examine whether hinokitiol can treat a $S$. pyogenes strain (A458) that has shown resistance to several types of antimicrobials, without being impeded, at least momentarily, by AMR. Since there is a variety of antimicrobials on the market we decided to compare hinokitiol with some gold-standard treatments for a general idea of its efficacy. The danger and rising prevalence of AMR $S$. pyogenes make this research a significant undertaking.

Considering S. pyogenes (A458) genetic similarity to $S$. pneumoniae and $S$. pyogenes (SSI-9), it was found that hinokitiol may have antibacterial effects according to previous studies $[4,6]$. Therefore, there is reason to believe that hinokitiol affects $S$. pyogenes (A458) as well. Hinokitiol has shown to have strong antibacterial effects, making it a suitable candidate $[4,6]$.

In vivo studies as well as experiments on the efficacy of hinokitiol against other antibiotic-resistant organisms should be conducted in the future to support the hypothesis of its efficacy.

\section{List of Abbreviations Used}

S. pyogenes: Streptococcus pyogenes

S. pneumoniae: Streptococcus pneumoniae

AMR: antimicrobial resistance

MTT: thiazolyl blue tetrazolium bromide

WHO: World Health Organization

ATP: adenosine triphosphate

EC50: effective concentration for $50 \%$ of the population

SPSS: statistical package for the social sciences

ANOVA: analysis of variance

RM ANOVA: repeated measures analysis of variance

\section{Conflicts of Interest}

The authors declare that they have no conflicts of interest.

Ethics Approval and/or Participant Consent

Ethics approval for the use of human cells and bacteria will be sought from Public Health Ontario.

\section{Authors' Contributions}

AAGS: worked on general research, introduction, methods, results, discussion, conclusion, and miscellaneous.

YJ: worked on general research, introduction, methods, results, discussion, conclusion, and miscellaneous.

SK: worked on general research, introduction, methods, results, discussion, conclusion, and miscellaneous.

OO: worked on general research, introduction, methods, results, discussion, conclusion, and miscellaneous.

\section{Acknowledgements}

The authors would like to thank Queen's University at Kingston for providing the resources to formulate this proposal.

\section{Funding}

This study was not funded.

\section{References}

[1] Kanwal S, Vaitla P. Streptococcus Pyogenes. In: StatPearls [Internet]. Treasure Island (FL): StatPearls Publishing; 2020 [cited 2020 Nov 21]. Available from: http://www.ncbi.nlm.nih.gov/books/NBK554528/

[2] Cattoir V. Mechanisms of antibiotic resistance. Oklahoma City (OK): University of Oklahoma Health Sciences Center; 2016.

[3] New report calls for urgent action to avert antimicrobial resistance crisis [Internet]. [cited 2020 Nov 21]. Available from: https://www.who.int/news/ item/29-04-2019-new-report-calls-for-urgent-action-toavert-antimicrobial-resistance-crisis 
UNDERGRADUATE RESEARCH IN NATURAL AND CLINICAL SCIENCE AND TECHNOLOGY (URNCST) JOURNAL Read more URNCST Journal articles and submit your own today at: https://www.urncst.com

[4] Domon H, Hiyoshi T, Maekawa T, Yonezawa D, Tamura H, Kawabata S, et al. Antibacterial activity of hinokitiol against both antibiotic-resistant and susceptible pathogenic bacteria that predominate in the oral cavity and upper airways. Microbiology and Immunology. 2019;63(6):213-22. https://doi.org/ $10.1111 / 1348-0421.12688$

[5] Terao Y, Kawabata S, Kunitomo E, Nakagawa I, Hamada S. Novel laminin-binding protein of Streptococcus pyogenes, Lbp, is involved in adhesion to epithelial cells. Infection and Immunity. $2002 \mathrm{Feb}$ 1;70(2):993-7. https://doi.org/10.1128/IAI.70.2.993997.2002

[6] Isono T, Domon H, Nagai K, Maekawa T, Tamura H, Hiyoshi T, et al. Treatment of severe pneumonia by hinokitiol in a murine antimicrobial-resistant Pneumococcal pneumonia model. PLOS ONE. 2020 Oct 15;15(10):e0240329. https://doi.org/10.1371/ journal.pone.0240329

[7] $\mathrm{WHO}$ | Infographics: Antibiotic resistance [Internet]. WHO. World Health Organization; 2015 [cited 2021 Feb 27]. Available from: https://www.euro.who.int/_data/assets/image/0009/32 9085/WAAW-2016-infographic-causes.jpg
[8] Horodniceanu T, Buu-Hoï A, Delbos F, Bieth G. Highlevel aminoglycoside resistance in group A, B, G, D (Streptococcus bovis), and Viridans streptococci. Antimicrobial Agents and Chemotherapy. 1982 Jan;21(1):176-9. https://doi.org/10.1128/aac.21.1.176

[9] Riss TL, Moravec RA, Niles AL, et al. Cell viability assays. 2013 May 1 [Updated 2016 Jul 1]. In: Markossian S, Sittampalam GS, Grossman A, et al., editors. Assay Guidance Manual [Internet]. Bethesda (MD): Eli Lilly \& Company and the National Center for Advancing Translational Sciences; 2004-. Available from: https://www.ncbi.nlm.nih.gov/books/ NBK144065/

[10] Veyssier-Belot C, Lejoyeux-Chartier F, Bouvet A. Erysipèle, cellulites et autres infections cutanées sévères à Streptococcus pyogenes [Erysipelas, cellulitis and other severe Streptococcus pyogenes skin infections]. Presse Med. 1999 Nov 13;28(35):1959-65. French.

\author{
Article Information \\ Managing Editor: Jeremy Y. Ng \\ Peer Reviewers: Mythili Ravishankar, Jordan Donders, Daniel Tarade \\ Article Dates: Received Apr 04 21; Accepted Jul 10 21; Published Aug 1121
}

\title{
Citation
}

Please cite this article as follows:

Golrokhian-Sani AA, Jiang Y, Kaka S, Olanrewaju O. Is hinokitiol efficacious against an antimicrobial-resistant strain of Streptococcus pyogenes?: A research protocol. URNCST Journal. 2021 Aug 11: 5(8).

https://urncst.com/index.php/urncst/article/view/277

DOI Link: https://doi.org/10.26685/urncst.277

\section{Copyright}

(C) Amir-Ali Golrokhian-Sani, Yunbo Jiang, Sinan Kaka, Olamide Olanrewaju. (2021). Published first in the Undergraduate Research in Natural and Clinical Science and Technology (URNCST) Journal. This is an open access article distributed under the terms of the Creative Commons Attribution License (https://creativecommons.org/licenses/by/4.0/), which permits unrestricted use, distribution, and reproduction in any medium, provided the original work, first published in the Undergraduate Research in Natural and Clinical Science and Technology (URNCST) Journal, is properly cited. The complete bibliographic information, a link to the original publication on http://www.urncst.com, as well as this copyright and license information must be included. 
UNDERGRADUATE RESEARCH IN NATURAL AND CLINICAL SCIENCE AND TECHNOLOGY (URNCST) JOURNAL

Read more URNCST Journal articles and submit your own today at: https://www.urncst.com

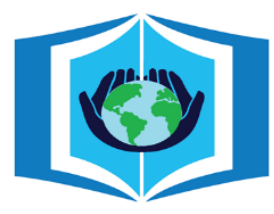

\section{URNCST Journal \\ "Research in Earnest"}

\section{Funded by the Government of Canada}

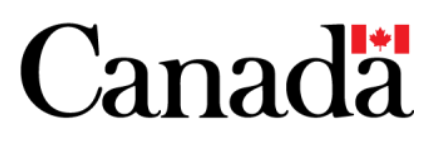

Do you research in earnest? Submit your next undergraduate research article to the URNCST Journal!

| Open Access | Peer-Reviewed | Rapid Turnaround Time | International |

| Broad and Multidisciplinary | Indexed | Innovative | Social Media Promoted |

Pre-submission inquiries? Send us an email at info@urncst.com | Facebook, Twitter and LinkedIn: @URNCST

Submit YOUR manuscript today at https://www.urncst.com! 